\title{
Pyridinolysis of Dicyclohexyl Phosphinic Chloride in Acetonitrile
}

\author{
Md. Ehtesham Ul Hoque and Hai Whang Lee* \\ Department of Chemistry, Inha University, Incheon 402-751, Korea. *E-mail: hwlee@inha.ac.kr \\ Received April 26, 2011, Accepted May 2, 2011
}

Key Words : Phosphoryl transfer reaction, Pyridinolysis, Dicyclohexyl phosphinic chloride, Biphasic concave upward free energy relationship

In previous work, this lab studied the aminolyses of various types of phosphates and derivatives: pyridinolysis, ${ }^{1}$ anilinolysis, ${ }^{2}$ benzylaminolysis, ${ }^{3}$ and theoretical study. ${ }^{4}$ In the present work, the nucleophilic substitution reactions of dicyclohexyl phosphinic chloride [3: $\left.\operatorname{cHex}_{2} \mathrm{P}(=\mathrm{O}) \mathrm{Cl}\right]$ with substituted $\mathrm{X}$-pyridines are investigated kinetically in acetonitrile at $55.0 \pm 0.1{ }^{\circ} \mathrm{C}$ to gain further understanding of phosphoryl transfer reaction mechanism (Scheme 1). The kinetic results of the pyridinolyses of five $\mathrm{R}_{1} \mathrm{R}_{2} \mathrm{P}(=\mathrm{O}) \mathrm{Cl}$ type substrates are discussed on the basis of steric and inductive effects of the two ligands $\left(\mathrm{R}_{1}\right.$ and $\left.\mathrm{R}_{2}\right)$ on the reactivity and mechanism. Employed substrates are dimethyl [1: $\left.\mathrm{Me}_{2} \mathrm{P}(=\mathrm{O}) \mathrm{Cl}\right],{ }^{1 \mathrm{~h}}$ diethyl $\left[2: \mathrm{Et}_{2} \mathrm{P}(=\mathrm{O}) \mathrm{Cl}\right],{ }^{1 \mathrm{i}}$ dicyclohexyl (3), methyl phenyl [4: $\mathrm{MePhP}(=\mathrm{O}) \mathrm{Cl}]^{1 \mathrm{~m}}$ and diphenyl phosphinic chloride [5: $\left.\mathrm{Ph}_{2} \mathrm{P}(=\mathrm{O}) \mathrm{Cl}\right] .{ }^{1 \mathrm{~d}}$ The numbering of the substrates (1-5) follows the sequence of the size of the two ligand, $\mathrm{R}_{1}$ and $\mathrm{R}_{2}$. Herein, $\mathrm{R}_{1}$ and $\mathrm{R}_{2}$ are alkyl and/or phenyl ligands.

\section{Results and Discussion}

The reactions were carried out under pseudo-first-order conditions with a large excess of pyridine. The observed pseudo-first-order rate constants $\left(k_{\text {obsd }}\right)$ for all reactions obeyed eq. (1) with negligible $k_{0}(=0)$ in $\mathrm{MeCN}$. The second-order rate constants were determined with at least five pyridine concentrations. The linear plots of eq. (1) suggest a lack of any base-catalysis or side reactions, and the overall reaction is described by Scheme 1 .

$$
k_{\text {obsd }}=k_{0}+k_{2}\left[\mathrm{XC}_{5} \mathrm{H}_{4} \mathrm{~N}\right]
$$

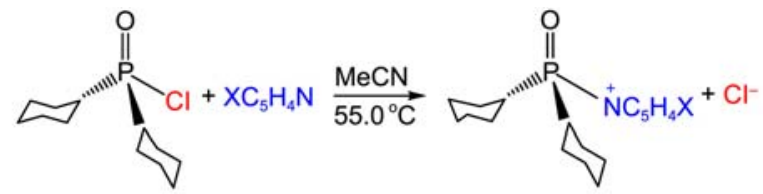

$\mathrm{X}=4-\mathrm{MeO}, 4-\mathrm{Me}, 3-\mathrm{Me}, \mathrm{H}, 3-\mathrm{Ph}, 3-\mathrm{MeO}, 3-\mathrm{Cl}, 3-\mathrm{Ac}, 4-\mathrm{Ac}, 3-\mathrm{CN}, 4-\mathrm{CN}$

Scheme 1. The studied reaction system.
The second-order rate constants $\left[k_{2}\left(\mathrm{M}^{-1} \mathrm{~s}^{-1}\right)\right]$ are summarized in Table 1 . The Brönsted $\beta_{\mathrm{X}}$ values were calculated by correlating $\log k_{2}(\mathrm{MeCN})$ with $\mathrm{p} K_{\mathrm{a}}\left(\mathrm{H}_{2} \mathrm{O}\right),{ }^{5}$ which was justified theoretically and experimentally. ${ }^{6}$ The substituent effects of the nucleophiles upon the pyridinolysis rates correlate with those for a typical nucleophilic substitution reaction where the stronger nucleophile leads to a faster rate. However, both the Hammett $\left(\log k_{2} v s \sigma_{\mathrm{X}}\right.$; Fig. 1) and Brönsted [ $\log k_{2}$ vs $\mathrm{p} K_{\mathrm{a}}(\mathrm{X})$; Fig. 2] plots are biphasic concave upwards with a break point at $\mathrm{X}=3-\mathrm{Ph}$. The magnitudes of $\rho_{\mathrm{X}}(=-6.02)$ and $\beta_{\mathrm{X}}(=1.23)$ values with the strongly basic pyridines ( $\mathrm{X}=4-\mathrm{MeO}, 4-\mathrm{Me}, 3-\mathrm{Me}, \mathrm{H}, 3-\mathrm{Ph})$ are much greater than those $\left(\rho_{\mathrm{X}}=-0.85\right.$ and $\left.\beta_{\mathrm{X}}=0.14\right)$ with the weakly basic pyridines ( $\mathrm{X}=3-\mathrm{Ph}, 3-\mathrm{MeO}, 3-\mathrm{Cl}, 3-\mathrm{Ac}, 4-$ Ac, 3-CN, 4-CN).

Table 2 shows the natural bond order (NBO) charges at the reaction center $\mathrm{P}$ atom in the gas phase $[\mathrm{B} 3 \mathrm{LYP} / 6-$ $311+\mathrm{G}(\mathrm{d}, \mathrm{p})$ level of theory $]^{7}$ summations of the Taft's steric

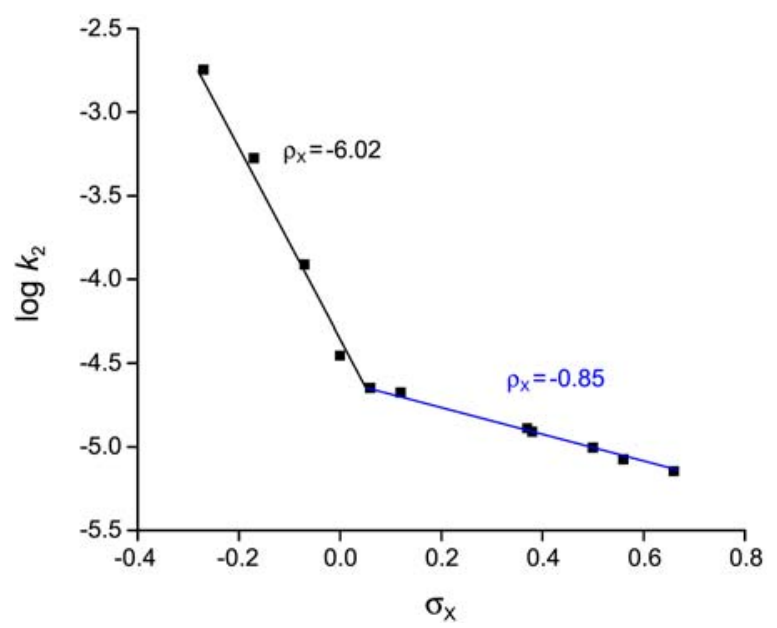

Figure 1. The Hammett plots $\left(\log k_{2} v s \sigma_{\mathrm{X}}\right)$ of the reactions of 3 $\left[\mathrm{cHex}_{2} \mathrm{P}(=\mathrm{O}) \mathrm{Cl}\right]$ with $\mathrm{X}$-pyridines in $\mathrm{MeCN}$ at $55.0^{\circ} \mathrm{C}$. The values of $\rho_{\mathrm{X}}$ are $-6.02 \pm 0.08(r=0.996)$ with $\mathrm{X}=(4-\mathrm{MeO}, 4-\mathrm{Me}, 3-\mathrm{Me}$, $\mathrm{H}, 3-\mathrm{Ph})$ and $-0.85 \pm 0.01(r=0.999)$ with $\mathrm{X}=(3-\mathrm{Ph}, 3-\mathrm{MeO}, 3-$ $\mathrm{Cl}, 3-\mathrm{Ac}, 4-\mathrm{Ac}, 3-\mathrm{CN}, 4-\mathrm{CN})$.

Table 1. Second-order rate constants $\left(k_{2} \times 10^{5} / \mathrm{M}^{-1} \mathrm{~s}^{-1}\right)$ of the reactions of $3\left[\mathrm{cHex}_{2} \mathrm{P}(=\mathrm{O}) \mathrm{Cl}\right]$ with $\mathrm{XC}_{5} \mathrm{H}_{4} \mathrm{~N}$ in $\mathrm{MeCN}$ at $55.0{ }^{\circ} \mathrm{C}$

\begin{tabular}{cccccccccccc}
\hline $\mathrm{X}$ & $4-\mathrm{MeO}$ & $4-\mathrm{Me}$ & $3-\mathrm{Me}$ & $\mathrm{H}$ & $3-\mathrm{Ph}$ & $3-\mathrm{MeO}$ & $3-\mathrm{Cl}$ & $3-\mathrm{Ac}$ & $4-\mathrm{Ac}$ & $3-\mathrm{CN}$ & $4-\mathrm{CN}$ \\
\hline \multirow{2}{*}{$k_{2} \times 10^{5}$} & 180 & 53.0 & 12.2 & 3.52 & 2.25 & 2.11 & 1.29 & 1.23 & 0.998 & 0.842 & 0.714 \\
& \pm 2 & \pm 0.3 & \pm 0.1 & \pm 0.03 & \pm 0.02 & \pm 0.01 & \pm 0.01 & \pm 0.01 & \pm 0.010 & \pm 0.009 & \pm 0.006 \\
\hline
\end{tabular}




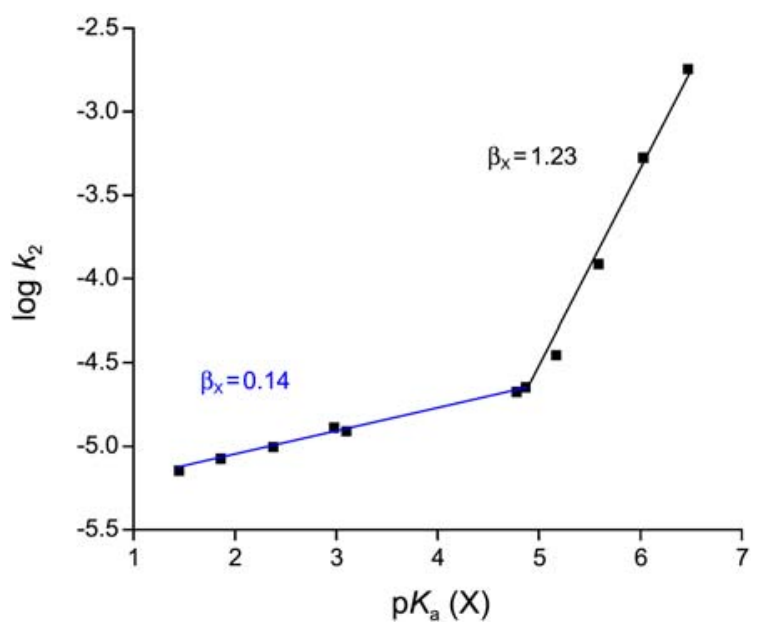

Figure 2. The Brönsted plots $\left[\log k_{2} v s \mathrm{p} K_{\mathrm{a}}(\mathrm{X})\right]$ of the reactions of $3\left[\mathrm{cHex}_{2} \mathrm{P}(=\mathrm{O}) \mathrm{Cl}\right]$ with $\mathrm{X}$-pyridines in $\mathrm{MeCN}$ at $55.0{ }^{\circ} \mathrm{C}$. The values of $\beta_{\mathrm{X}}$ are $1.23 \pm 0.08(r=0.996)$ with $\mathrm{X}=(4-\mathrm{MeO}, 4-\mathrm{Me}, 3-$ $\mathrm{Me}, \mathrm{H}, 3-\mathrm{Ph})$ and $0.14 \pm 0.02(r=0.997)$ with $\mathrm{X}=(3-\mathrm{Ph}, 3-\mathrm{MeO}$, 3-Cl, 3-Ac, 4-Ac, 3-CN, 4-CN).

constants $\left[\Sigma E_{\mathrm{S}}=E_{\mathrm{S}}\left(\mathrm{R}_{1}\right)+\Sigma E_{\mathrm{S}}\left(\mathrm{R}_{2}\right)\right]^{8}$ and Charton's corrected atomic radii $\left[\Sigma v_{\mathrm{x}}=v_{\mathrm{x}}\left(\mathrm{R}_{1}\right)+v_{\mathrm{x}}\left(\mathrm{R}_{2}\right)\right]^{9}$ of the two ligands, second-order rate constants $\left(k_{2}\right)$ with unsubstituted pyridine $\left(\mathrm{C}_{5} \mathrm{H}_{5} \mathrm{~N}\right)$ at $35.0^{\circ} \mathrm{C}$, and Brönsted coefficients $\left(\beta_{\mathrm{X}}\right)$ for the pyridinolyses of five $\mathrm{R}_{1} \mathrm{R}_{2} \mathrm{P}(=\mathrm{O})$ Cl-type phosphinic chlorides in $\mathrm{MeCN}$. Solely considering the magnitude of the positive charge of the reaction center $\mathrm{P}$ atom in the substrate, the sequence of the pyridinolysis rate should be $\mathbf{3}>\mathbf{5}>\mathbf{4}>\mathbf{2}$ $>1$. When the steric effects of the two ligands, $R_{1}$ and $R_{2}$, play an important role to determine the pyridinolysis rate, the sequence of the rate should be $\mathbf{1}>\mathbf{2}>\mathbf{3}>\mathbf{4}>\mathbf{5}$. However, the observed sequence of the second-order rate constants of the pyridinolyses, $\mathbf{4}>\mathbf{1}>\mathbf{2}>\mathbf{5}>>\mathbf{3}$ [the relative rate ratio of $7.6 \times 10^{6}(\mathbf{4}): 6.1 \times 10^{6}(\mathbf{1}): 7.7 \times 10^{3}(\mathbf{2})$ $: 3.2 \times 10^{3}(\mathbf{5}): 1(\mathbf{3})$ ], does not show systematic consistency with the NBO charge at $\mathrm{P}$ atom, $\Sigma E_{\mathrm{S}}$, or $\Sigma v_{\mathrm{x}}$. These results indicate that the pyridinolysis rates of $\mathrm{R}_{1} \mathrm{R}_{2} \mathrm{P}(=\mathrm{O}) \mathrm{Cl}$ in $\mathrm{MeCN}$ are not dependent upon one dominant factor but on many factors. On the contrary, the anilinolysis rates of the phosphinic chlorides are predominantly dependent upon the steric effects of the two ligands. The second-order rate constants for the reactions of five phosphinic chlorides with $\mathrm{C}_{6} \mathrm{H}_{5} \mathrm{NH}_{2}$ in $\mathrm{MeCN}$ at $55.0^{\circ} \mathrm{C}$ gave the relative rate ratio of $8.32 \times 10^{5}(\mathbf{1})^{2 \mathrm{i}}: 2.01 \times 10^{4}(\mathbf{2})^{21}: 1.47 \times 10^{4}(\mathbf{4})^{2 \mathrm{i}}: 1.84 \times$ $10^{2}(\mathbf{5})^{2 \mathrm{~d}}: 1(\mathbf{3}){ }^{2 \mathrm{n}}$ When 3 is not considered, the sequence of the anilinolysis rates of the phosphinic chlorides, $1>>2>4$ $>>\mathbf{5}$, is inversely proportional to the size of the two ligands; $\mathrm{Ph}, \mathrm{Ph}(\mathbf{5})>\mathrm{Ph}, \mathrm{Me}(\mathbf{4})>\operatorname{Et}, \mathrm{Et}(\mathbf{2})>\mathrm{Me}, \mathrm{Me}(\mathbf{1})$. The greater the size of the two ligands, the anilinolysis rate becomes slower, i.e., the relative rate ratio of $4,520(\mathbf{1})^{2 \mathrm{i}}: 109(\mathbf{2})^{21}: 80(\mathbf{4})^{2 \mathrm{i}}$ : $1(\mathbf{5}) .^{2 \mathrm{~d}}$

Meanwhile, the pyridinolysis rate is rather faster than the corresponding anilinolysis rate: $k_{\mathrm{Pyr}}\left(35.0^{\circ} \mathrm{C}\right) / k_{\mathrm{An}}\left(55.0^{\circ} \mathrm{C}\right)=$ $13(\mathbf{1}),{ }^{1 \mathrm{~h}, 2 \mathrm{i}} 0.67(\mathbf{2}),{ }^{1 \mathrm{i}, 21,11} 1.8(\mathbf{3}),{ }^{2 \mathrm{n}} 910(\mathbf{4}),{ }^{1 \mathrm{~m}, 2 \mathrm{i}}$ and $32(\mathbf{5}) .^{1 \mathrm{~d}, 2 \mathrm{~d}}$ The difference in the rate may be due to resonance energy gain from the benzyl cation type $\pi$-complex formation of pyridine with an empty $d$-orbital of the $\mathrm{P}$ atom. This type of $\pi$-complex is not possible with aniline because the lone pair on the amino nitrogen is a $p$-type so that the horizontal $\pi$ cloud of the ring overlap with the $d$-orbital of P marginally. Moreover, regarding the steric effects of the two ligands, the horizontal approach of the aniline ring should cause excessive steric hindrance in contrast to a much less steric effects in the vertical approach of the pyridine ring. . $^{\mathrm{a}, \mathrm{m}}$

As can be seen in Table 2, the pyridinolysis rate of $\mathbf{3}$ is too slow to be rationalized by normal stereoelectronic effects. The anilinolysis rate of $\mathbf{3}$ was also exceptionally slow, and the authors tentatively suggested that the exceptionally slow rate of the anilinolysis of $\mathbf{3}$ is attributed to an unexpected steric hindrance of the two cyclohexyl ligands which cannot be predicted by the Taft's $\Sigma E_{\mathrm{S}}$ and Charton's $\Sigma v_{\mathrm{x}}{ }^{2 \mathrm{n}}$ At this point, considering the very slow rate of the pyridinolysis, the authors suggest that the exceptionally slow rate of the aminolysis (both anilinolysis and pyridinolysis) is ascribed to the ultimate nature of $\mathbf{3}$, and further studies are required to clarify the considerably low reactivity.

The $\mathrm{S}_{\mathrm{N}} 2$ reaction mechanism was proposed for the pyridinolyses of $\mathbf{2}$ and $\mathbf{5}$ with both frontside (TSf) and backside attacks (TSb), and the fraction of a frontside attack is more or less larger than that of a backside attack, on the basis of the magnitudes of $\beta_{\mathrm{X}}$ values. ${ }^{1 \mathrm{~d}, \mathrm{i}}$

Table 2. Summary of the NBO charges at the reaction center $\mathrm{P}$ atom, summations of the Taft's steric constants $\left(\Sigma E_{\mathrm{S}}\right)$ and Charton's corrected atomic radii $\left(\Sigma v_{\mathrm{x}}\right)$ of the two ligands, second-order rate constants $\left(k_{2}\right.$ with $\mathrm{C}_{5} \mathrm{H}_{5} \mathrm{~N}$ at $\left.35.0{ }^{\circ} \mathrm{C}\right)$, and Brönsted coefficients $\left(\beta_{\mathrm{X}}\right)$ for the pyridinolyses of $\mathbf{1}, \mathbf{2}, \mathbf{3}, \mathbf{4}$, and $\mathbf{5}$ in $\mathrm{MeCN}$

\begin{tabular}{|c|c|c|c|c|c|c|}
\hline Substrate & charge at $P$ & $-\Sigma E_{\mathrm{S}}$ & $\Sigma v_{\mathrm{x}}$ & $k_{2} \times 10^{3 a}$ & $\beta_{\mathrm{X}}$ & Ref \\
\hline 1: $\mathrm{Me}_{2} \mathrm{P}(=\mathrm{O}) \mathrm{Cl}$ & 1.793 & 0.00 & 1.04 & $102,000^{b}$ & $0.17^{e} /-0.03^{f}$ & $1 \mathrm{~h}$ \\
\hline 2: $\mathrm{Et}_{2} \mathrm{P}(=\mathrm{O}) \mathrm{Cl}$ & 1.817 & 0.14 & 1.08 & 127 & $0.45^{g}$ & $1 \mathrm{i}$ \\
\hline 3: $\operatorname{cHex}_{2} \mathrm{P}(=\mathrm{O}) \mathrm{Cl}$ & 1.863 & 1.58 & 1.74 & $0.0166^{c}$ & $1.23^{h} / 0.14^{i}$ & this work \\
\hline 4: $\mathrm{MePhP}(=\mathrm{O}) \mathrm{Cl}$ & 1.821 & 2.48 & 2.18 & $126,000^{d}$ & $-0.48^{j} / 1.17^{k}$ & $1 \mathrm{~m}$ \\
\hline 5: $\mathrm{Ph}_{2} \mathrm{P}(=\mathrm{O}) \mathrm{Cl}$ & 1.844 & 4.96 & 3.32 & 54.6 & $0.68^{l}$ & $1 d$ \\
\hline
\end{tabular}

${ }^{a}$ Second-order rate constant with unsubstituted pyridine $(\mathrm{X}=\mathrm{H})$ at $35.0{ }^{\circ} \mathrm{C} .{ }^{b}$ Extrapolated value in the Arrhenius plot with kinetic data: $k_{2}=34,300$, 40,400 , and $53,900 \times 10^{-3} \mathrm{M}^{-1} \mathrm{~s}^{-1}$ at $-25.0,-15.0$, and $-5.0^{\circ} \mathrm{C}$, respectively. ${ }^{c}$ Empirical kinetic value. See ref $10 .{ }^{d}$ Extrapolated value in the Arrhenius plot with kinetic data: $k_{2}=46,100,50,300$, and $55,800 \times 10^{-3} \mathrm{M}^{-1} \mathrm{~s}^{-1}$ at $-30.0,-25.0$, and $-20.0{ }^{\circ} \mathrm{C}$, respectively. ${ }^{e}$ The value at $-25.0{ }^{\circ} \mathrm{C}$. For $\mathrm{X}=(4-$ $\mathrm{MeO}, 4-\mathrm{Me}, 3-\mathrm{Me}, \mathrm{H}, 3-\mathrm{Ph}) .{ }^{f} \mathrm{The}$ value at $-25.0^{\circ} \mathrm{C}$. For $\mathrm{X}=(3-\mathrm{MeO}, 3-\mathrm{Cl}, 3-\mathrm{Ac}, 4-\mathrm{Ac}, 3-\mathrm{CN}, 4-\mathrm{CN}) .{ }^{g} \mathrm{The}$ value at $45.0^{\circ} \mathrm{C} .{ }^{h} \mathrm{The}$ value at $55.0^{\circ} \mathrm{C}$. For $\mathrm{X}=(4-\mathrm{MeO}, 4-\mathrm{Me}, 3-\mathrm{Me}, \mathrm{H}, 3-\mathrm{Ph}) .{ }^{i} \mathrm{The}$ value at $55.0^{\circ} \mathrm{C}$. For $\mathrm{X}=(3-\mathrm{Ph}, 3-\mathrm{MeO}, 3-\mathrm{Cl}, 3-\mathrm{Ac}, 4-\mathrm{Ac}, 3-\mathrm{CN}, 4-\mathrm{CN}) .{ }^{j} \mathrm{The}$ value at $-20.0{ }^{\circ} \mathrm{C}$. For $\mathrm{X}=(4-$

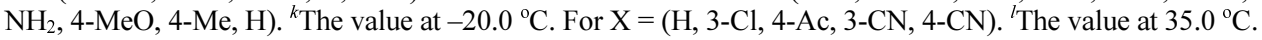



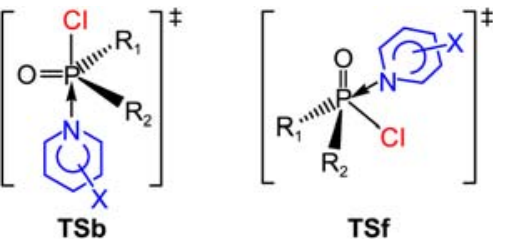

In the pyridinolyses of $\mathbf{1}$ at $-25.0^{\circ} \mathrm{C},{ }^{1 \mathrm{~h}}$ a concerted mechanism was proposed, and biphasic concave upward free energy relationships was interpreted as a change of nucleophilic attacking direction from a frontside attack (TSf) with the strongly basic pyridines to a backside attack (TSb) with the weakly basic pyridines. Empirical kinetic results showed that the $\rho_{\mathrm{x}}$ value changes from +0.16 (positive) via -0.34 (negative) to -0.38 (negative) as the reaction temperature changes from -25.0 via -20.0 to $-15.0^{\circ} \mathrm{C}$, resulting in $t_{\text {isokinetic }}=-23.8^{\circ} \mathrm{C}^{1 \mathrm{~h}}$ In the pyridinolyses of 4 at $-20.0^{\circ} \mathrm{C}$, ${ }^{1 \mathrm{~h}}$ a stepwise mechanism with a rate-limiting step change from bond breaking with the weakly basic pyridines to bond formation with the strongly basic pyridines was proposed on the basis of biphasic concave downward Hammett and Brönsted plots. Unusual positive $\rho_{\mathrm{X}}$ and negative $\beta_{\mathrm{X}}$ values were rationalized by the isokinetic relationship (calculated isokinetic temperature of $\left.t_{\text {isokinetic }}=+14.4{ }^{\circ} \mathrm{C}\right) .{ }^{1 \mathrm{~m}}$

The concave upward Hammett and Brönsted plots for substituent $\mathrm{X}$ variations in the nucleophiles were also observed for the pyridinolyses of $\mathrm{R}_{1} \mathrm{R}_{2} \mathrm{P}(=\mathrm{S}) \mathrm{Cl}$-type substrates: dimethyl $\left[(\mathrm{MeO})_{2} \mathrm{P}(=\mathrm{S}) \mathrm{Cl}\right]^{1 \mathrm{~g}}$ and diethyl $\left[(\mathrm{EtO})_{2} \mathrm{P}(=\mathrm{S}) \mathrm{Cl}\right]^{1 \mathrm{~g}}$ chlorothiophosphates, dimethyl $\left[\mathrm{Me}_{2} \mathrm{P}(=\mathrm{S}) \mathrm{Cl}\right],{ }^{1 \mathrm{~h}}$ and diphenyl $\left[\mathrm{Ph}_{2} \mathrm{P}(=\mathrm{S}) \mathrm{Cl}\right]^{1 \mathrm{~d}}$ thiophosphinic chlorides. The biphasic concave upward free energy correlations were substantiated by a change in the attacking direction of the nucleophile from a frontside attack with the strongly basic pyridines to a backside attack with the weakly basic pyridines. In general, the nonlinear free energy correlation of a concave upward plot is diagnostic of a change in the reaction mechanism, such as parallel reactions where the reaction path is changed depending on the substituents, while nonlinear free energy correlation of the biphasic concave downward plot is diagnostic of a rate-limiting step change from bond breaking with less basic nucleophiles to bond formation with more basic nucleophiles. ${ }^{12}$ It is the suggestion of the authors that the concave upward Hammett and Brönsted plots can also be diagnostic of a change in the attacking direction of the nucleophile depending on the substituents from backside to frontside. ${ }^{1 \mathrm{~g}, \mathrm{I}}$ It is worthy to note that a frontside attack (TSf) yields greater magnitudes of $\rho_{\mathrm{X}}$ and $\beta_{\mathrm{X}}$ values compared to a backside attack. $^{1 \mathrm{c}}$

In the present work, the authors propose a concerted $\mathrm{S}_{\mathrm{N}} 2$ mechanism is proposed, and biphasic concave upward free energy correlations is rationalized by a change of nucleophilic attacking direction from a frontside attack (TSf; $\rho_{\mathrm{X}}=$ -6.02 and $\beta_{\mathrm{X}}=1.23$ ) with the strongly basic pyridines to a backside attack (TSb; $\rho_{\mathrm{X}}=-0.85$ and $\beta_{\mathrm{X}}=0.14$ ) with the weakly basic pyridines.

In summary, the kinetic studies on the pyridinolysis of dicyclohexyl phosphinic chloride have been carried out in
$\mathrm{MeCN}$ at $55.0{ }^{\circ} \mathrm{C}$. The pyridinolysis rate is too slow to be rationalized by normal stereoelectonic effects. The authors suggest that the exceptionally slow rate of the aminolysis is ascribed to the ultimate nature of dicyclohexyl phosphinic chloride. The free energy correlations are biphasic concave upwards with a break point at $\mathrm{X}=3-\mathrm{Ph}$. A concerted $\mathrm{S}_{\mathrm{N}} 2$ mechanism is proposed with a change of the attacking direction of the nucleophile from a frontside attack (TSf) with the strongly basic pyridines to a backside attack (TSb) with the weakly basic pyridines.

\section{Experimental Section}

Materals. GR grade dicyclohexyl phosphinic chloride (more than 98\%) was used without further purification. GR grade pyridines and HPLC grade acetonitrile (less than $0.005 \%$ water content) were used without further purification.

Kinetic Procedure. Conductometric rate measurements were carried out using self-made computer-aided automatic A/D converter conductivity bridges. The pseudo-first-order rate constants $\left(k_{\text {obsd }}\right)$ were determined as previously described ${ }^{1 \mathrm{a}-\mathrm{i}}$ using large excess of nucleophiles, [substrate] $=0.003 \mathrm{M}$ and $\left[\mathrm{XC}_{5} \mathrm{H}_{4} \mathrm{~N}\right]=0.1-0.5 \mathrm{M}$. Each pseudo-first-order rate constants value $\left(k_{\mathrm{obsd}}\right)$ was averaged obtained from more than three runs.

Product Analysis. Dicyclohexyl phosphinic chloride was reacted with excess 4-methoxypyridine for more than 15 half-lives at $55.0{ }^{\circ} \mathrm{C}$ in acetonitrile. The insoluble product was washed several times with diethyl ether and isolated. The solvent was removed under reduced pressure. Analytical data of the products gave the following results:

$\left.\left[\mathbf{c H e x}{ }_{2} \mathbf{P}=\mathbf{O}\right) \mathbf{N C}_{\mathbf{5}} \mathbf{H}_{\mathbf{4}}-\mathbf{4 -} \mathbf{O C H}_{3}\right]^{+} \mathbf{C l}^{-}$. Brown gummy substance; ${ }^{1} \mathrm{H}$ NMR $\left(400 \mathrm{MHz}, \mathrm{CDCl}_{3}\right) \delta 8.34(\mathrm{~d}, J=6.4 \mathrm{~Hz}$, $2 \mathrm{H}$, pyridinium), $6.72(\mathrm{~d}, J=6.4 \mathrm{~Hz}, 2 \mathrm{H}$, pyridinium $), 3.74$ $\left(\mathrm{s}, 3 \mathrm{H}, \mathrm{OCH}_{3}\right), 1.63-1.99$ (12H, m, cyclohexyl), 1.08-1.41 (10H, m, cyclohexyl); ${ }^{13} \mathrm{C}$ NMR (100 MHz, $\left.\mathrm{CDCl}_{3}\right) \delta 25.26$, $25.61\left(\mathrm{CH}\right.$, cyclohexyl), 36.60, $37.47\left(\mathrm{CH}_{2}\right.$, cyclohexyl), $54.79\left(\mathrm{OCH}_{3}\right), 103.64,109.63,150.80,165.34(\mathrm{C}=\mathrm{C}$, pyridinium); ${ }^{31} \mathrm{P}$ NMR (162 MHz, $\left.\mathrm{CDCl}_{3}\right) \delta 63.05$ (s, 1P, P=O); $m / z, 360\left(\mathrm{M}^{+}\right)$.

Acknowledgments. This work was supported by the Brain Korea 21 Program from National Research Foundation of Korea.

\section{References and Notes}

1. (a) Guha, A. K.; Lee, H. W.; Lee, I. J. Org. Chem. 2000, 65, 12 (b) Lee, H. W.; Guha, A. K.; Kim, C. K.; Lee, I. J. Org. Chem. 2002, 67, 2215. (c) Adhikary, K. K.; Lee, H. W.; Lee, I. Bull. Korean Chem. Soc. 2003, 24, 1135. (d) Hoque, M. E. U.; Dey, N. K.; Guha, A. K.; Kim, C. K.; Lee, B. S.; Lee, H. W. Bull. Korean Chem. Soc. 2007, 28, 1797. (e) Adhikary, K. K.; Lumbiny, B. J.; Kim, C. K.; Lee, H. W. Bull. Korean Chem. Soc. 2008, 29, 851. (f) Lumbiny, B. J.; Adhikary, K. K.; Lee, B. S.; Lee, H. W. Bull. Korean Chem. Soc. 2008, 29, 1769. (g) Dey, N. K.; Hoque, M. E. U.; Kim, C. K.; Lee, H. W. J. Phys. Org. Chem. 2010, 23, 1022. (h) Dey, N. K.; Adhikary, K. K.; Kim, C. K.; Lee, H. W. Bull. Korean Chem. Soc. 2010, 31, 3856. (i) Dey, N. K.; Kim, C. K.; 
Lee, H. W. Bull. Korean Chem. Soc. 2011, 32, 709. (j) Hoque, M. E. U.; Dey, S.; Kim, C. K.; Lee, H. W. Bull. Korean Chem. Soc. 2011, 32, 1138. (k) Guha, A. K.; Hoque, M. E. U.; Lee, H. W. Bull. Korean Chem. Soc. 2011, 32, 1375. (1) Guha, A. K.; Kim, C. K.; Lee, H. W. J. Phys. Org. Chem. 2011, 24, 474. (m) Adhikary, K. K.; Lee, H. W. Bull. Korean Chem. Soc. 2011, 32, 1945.

2. (a) Guha, A. K.; Lee, H. W.; Lee, I. J. Chem. Soc., Perkin Trans. 2 1999, 765. (b) Lee, H. W.; Guha, A. K.; Lee, I. Int. J. Chem. Kinet. 2002, 34, 632. (c) Hoque, M. E. U.; Dey, S.; Guha, A. K.; Kim, C. K.; Lee, B. S.; Lee, H. W. J. Org. Chem. 2007, 72, 5493. (d) Hoque, M. E. U.; Lee, H. W. Bull. Korean Chem. Soc. 2007, 28, 936. (e) Dey, N. K.; Han, I. S.; Lee, H. W. Bull. Korean Chem. Soc. 2007, 28, 2003. (f) Hoque, M. E. U.; Dey, N. K.; Kim, C. K.; Lee, B. S.; Lee, H. W. Org. Biomol. Chem. 2007, 5, 3944. (g) Dey, N. K.; Hoque, M. E. U.; Kim, C. K.; Lee, B. S.; Lee, H. W. J. Phys. Org. Chem. 2008, 21, 544. (h) Lumbiny, B. J.; Lee, H. W. Bull. Korean Chem. Soc. 2008, 29, 2065. (i) Dey, N. K.; Hoque, M. E. U.; Kim, C. K.; Lee, B. S.; Lee, H. W. J. Phys. Org. Chem. 2009, 22, 425. (j) Dey, N. K.; Kim, C. K.; Lee, H. W. Bull. Korean Chem. Soc. 2009, 30, 975. (k) Hoque, M. E. U.; Guha, A. K.; Kim, C. K.; Lee, B. S.; Lee, H. W. Org. Biomol. Chem. 2009, 7 , 2919. (1) Dey, N. K.; Lee, H. W. Bull. Korean Chem. Soc. 2010, 31, 1403. (m) Dey, N. K.; Kim, C. K.; Lee, H. W. Org. Biomol. Chem. 2011, 9, 717. (n) Hoque, M. E. U.; Lee, H. W. Bull. Korean Chem. Soc. 2011, 32, 1997.

3. Adhikary, K. K.; Lee, H. W. Bull. Korean Chem. Soc. 2011, 32, 1625.

4. (a) Lee, I.; Kim, C. K.; Li, H. G.; Sohn, C. K.; Kim, C. K.; Lee, H. W.; Lee, B. S. J. Am. Chem. Soc. 2000, 122, 11162. (b) Han, I. S.; Kim, C. K.; Lee, H. W. Bull. Korean Chem. Soc. 2011, 32, 889.

5. (a) Fischer, A.; Galloway, W. J.; Vaughan, J. J. Chem. Soc. 1964, 3591. (b) Dean, J. A. Handbook of Organic Chemistry; McGrawHill: New York, 1987; Chapter 8.

6. (a) Lee, I.; Kim, C. K.; Han, I. S.; Lee, H. W.; Kim, W. K.; Kim, Y. B. J. Phys. Chem. B 1999, 103, 7302. (b) Coetzee, J. F. Prog. Phys. Org. Chem. 1967, 4, 45.
7. Hehre, W. J.; Random, L.; Schleyer, P. V. R.; Pople, J. A. Ab Initio Molecular Orbital Theory; Wiley: New York, 1986; Chapter 4.

8. Taft, R. W. Steric Effect in Organic Chemistry, Newman, M. S., Ed.; Wiley: New York, 1956; Chapter 3.

9. Exner, O. Correlation Analysis in Chemistry: Recent Advances; Chapman, N. B., Shorter, J., Eds.; Plenum Press: New York, 1978; p 439.

10. The observed second-order rate constants of the studied reaction are $k_{2}=1.66 \pm 0.02\left(35.0^{\circ} \mathrm{C}\right), 2.53 \pm 0.03\left(45.0^{\circ} \mathrm{C}\right)$, and $3.52 \pm$ $0.03 \times 10^{-5} \mathrm{M}^{-1} \mathrm{~s}^{-1}\left(55.0^{\circ} \mathrm{C}\right)$, and the activation parameters of $\Delta H^{\neq}=6.9 \pm 0.3 \mathrm{kcal} / \mathrm{mol}$ and $\Delta S^{\neq}=-58 \pm 1$ eu are obtained.

11. Taking into account the value of $k_{\mathrm{An}}=100 \times 10^{-3} \mathrm{M}^{-1} \mathrm{~s}^{-1}$ at 35.0 ${ }^{\circ} \mathrm{C}$ calculated by extrapolation in the Arrhenius plot $(r=0.999)$ with kinetic data: $k_{2}=117,162$, and $211 \times 10^{-3} \mathrm{M}^{-1} \mathrm{~s}^{-1}$ at 40.0 , 50.0 , and $60.0^{\circ} \mathrm{C}$, respectively, from ref 21 , the ratio of $k_{\mathrm{Pyr}}(35.0$ $\left.{ }^{\circ} \mathrm{C}\right) / k_{\mathrm{An}}\left(35.0^{\circ} \mathrm{C}\right)=\left(127 \times 10^{-3}\right) /\left(100 \times 10^{-3}\right)=1.27$ is obtained.

12. (a) Williams, A. Free Energy Relationships in Organic and Bioorganic Chemistry; RSC: Cambridge, UK, 2003; Chapter 7. (b) Ruff, A.; Csizmadia, I. G. Organic Reactions Equilibria, Kinetics and Mechanism; Elsevier: Amsterdam, Netherlands, 1994; Chapter 7. (c) Oh, H. K.; Lee, J. M.; Lee H. W.; Lee, I. Int. J. Chem. Kinet. 2004, 36, 434. (d) Oh, H. K.; Park, J. E.; Lee, H. W. Bull. Korean Chem. Soc. 2004, 25, 1041. (e) Oh, H. K.; Ku, M. H.; Lee, H. W.; Lee, I. J. Org. Chem. 2002, 67, 8995. (f) Castro, E. A.; Angel, M.; Campodonico, P.; Santos, J. G. J. Org. Chem. 2002, 67, 8911. (g) Castro, E. A.; Pavez, P.; Santos, J. G. J. Org. Chem. 2002, 67, 4494. (h) Oh, H. K.; Ku, M. H.; Lee, H. W.; Lee, I. J. Org. Chem. 2002, 67, 3874. (i) Castro, E. A.; Pavez, P.; Santos, J. G. J. Org. Chem. 2002, 67, 3129. (j) Castro, E. A.; Pavez, P.; Arellano, D.; Santos, J. G. J. Org. Chem. 2001, 66, 6571. (k) Spillane, W. J.; McGrath, P.; Brack, C.; O’Byrne, A. B. J. Org. Chem. 2001, 66, 6313. (1) Koh, H. J.; Han, K. L.; Lee, H. W.; Lee, I. J. Org. Chem. 2000, 65, 4706. (m) Humeres, E.; Debacher, N. A.; Sierra, M. M D.; Franco J. D.; Shutz, A. J. Org. Chem. 1998, 63, 1598. (n) Baynham, A. S.; Hibbert, F.; Malana, M. A. J. Chem. Soc., Perkin Trans 2 1993, 1711. 


\section{Pyridinolysis of Dicyclohexyl Phosphinic Chloride in Acetonitrile}

\section{Md. Ehtesham Ul Hoque and Hai Whang Lee*}

Department of Chemistry, Inha University, Incheon 402-751, Korea. *E-mail: hwlee@inha.ac.kr Received April 26, 2011, Accepted May 2, 2011

Key Words : Phosphoryl transfer reaction, Pyridinolysis, Dicyclohexyl phosphinic chloride, Biphasic concave upward free energy relationship

HOO 31 P apr090

Pulse Sequence: s2pul

$$
\begin{gathered}
{ }^{1} \mathrm{H} \text { NMR } \\
\left(400 \mathrm{MHz}, \mathrm{CDCl}_{3}\right)
\end{gathered}
$$
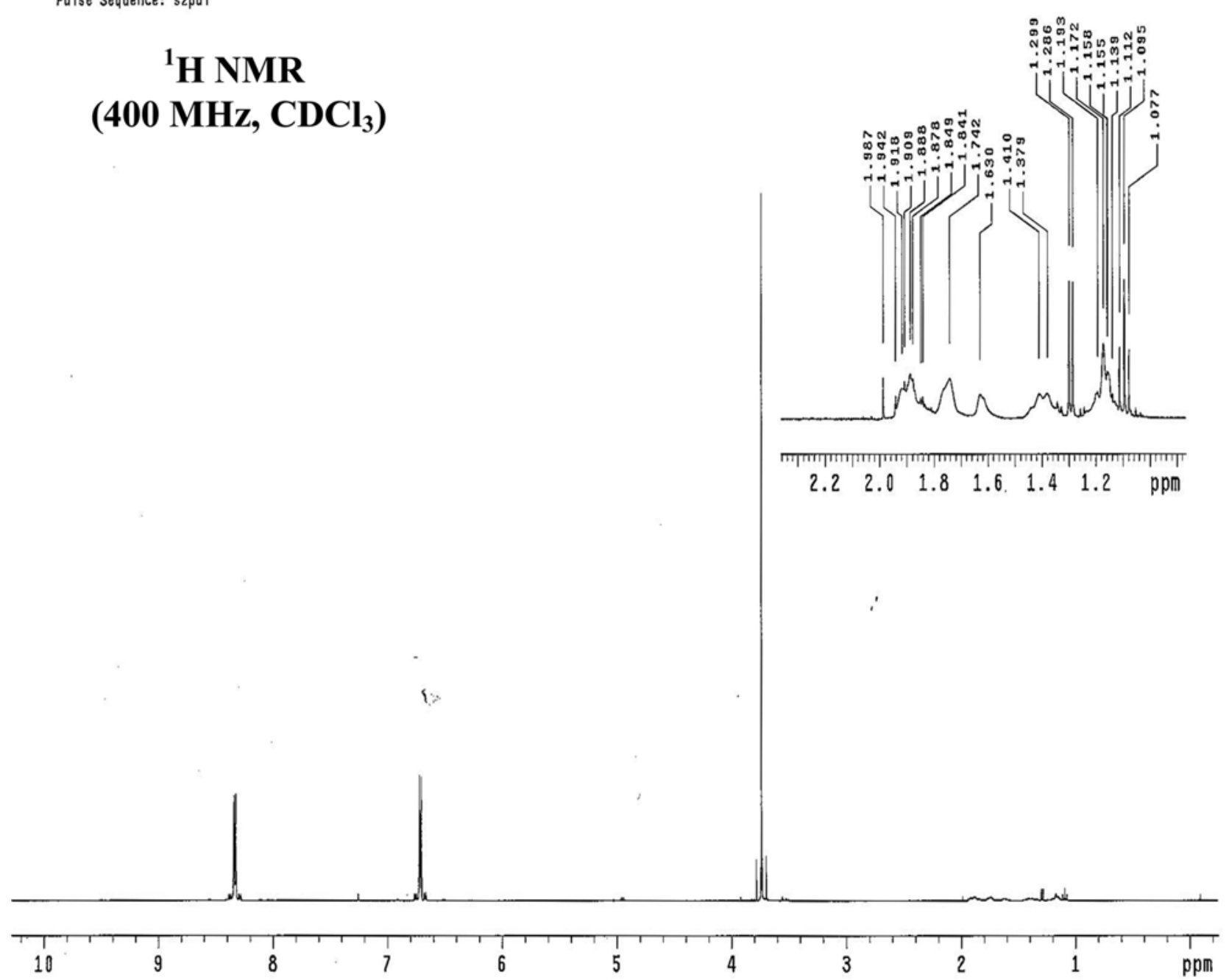

Figure S1. ${ }^{1} \mathrm{H}$ NMR spectrum of $\left[\mathrm{cHex}_{2} \mathrm{P}(=\mathrm{O}) \mathrm{NC}_{5} \mathrm{H}_{4}-4-\mathrm{OCH}_{3}\right]^{+} \mathrm{Cl}^{-}$. 
HOQ aprog1

Pulse Sequence: s2pul
${ }^{13} \mathrm{C}$ NMR

\section{(100 $\left.\mathrm{MHz}, \mathrm{CDCl}_{3}\right)$}

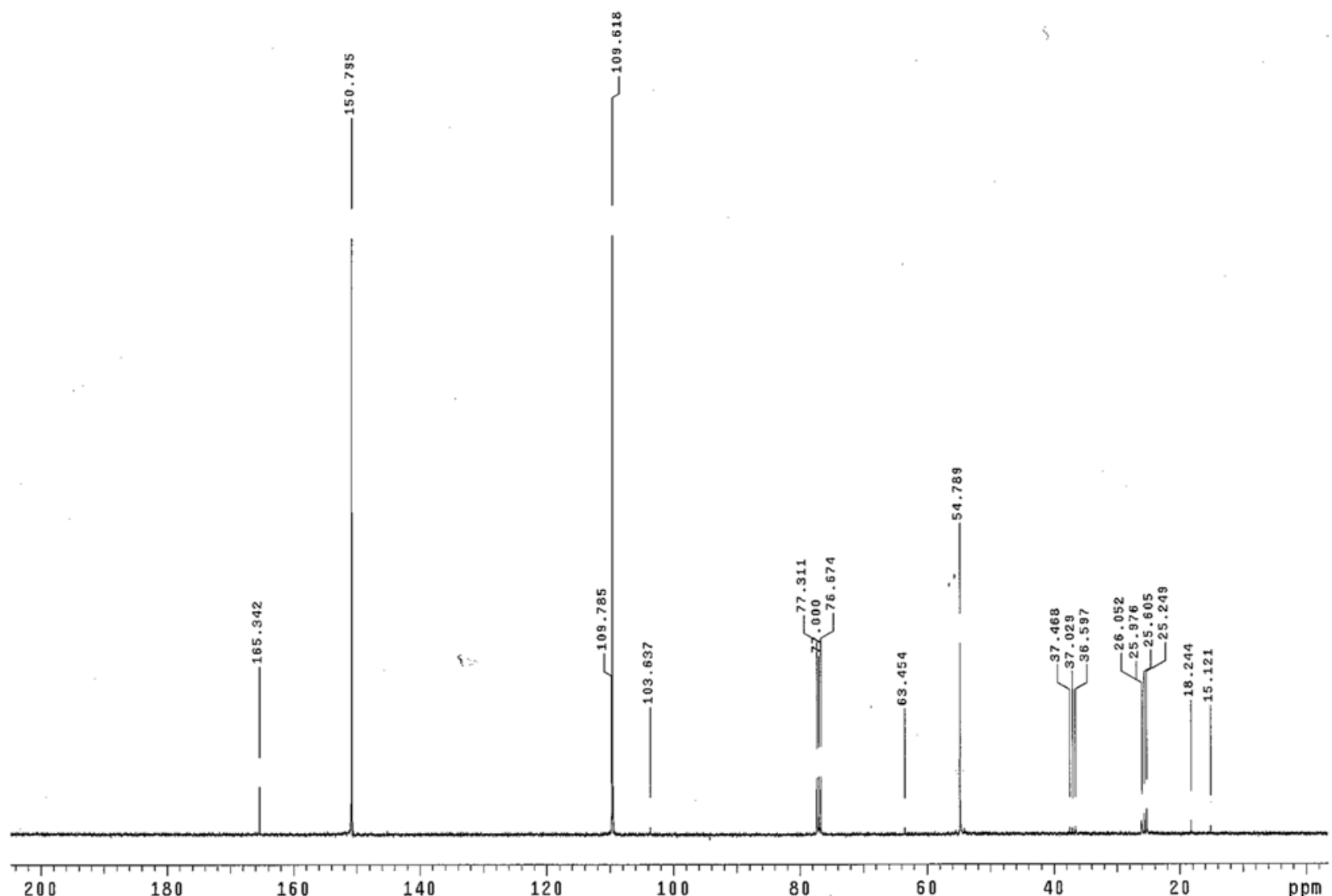

Figure S2. ${ }^{13} \mathrm{C}$ NMR spectrum of $\left[\mathrm{cHex}_{2} \mathrm{P}(=\mathrm{O}) \mathrm{NC}_{5} \mathrm{H}_{4}-4-\mathrm{OCH} 3\right]^{+} \mathrm{Cl}^{-}$. 
red 31P aproo1

Pulse Sequence: s2pul

\section{${ }^{31} \mathbf{P}$ NMR \\ (162 $\mathrm{MHz}, \mathrm{CDCl}_{3}$ )}

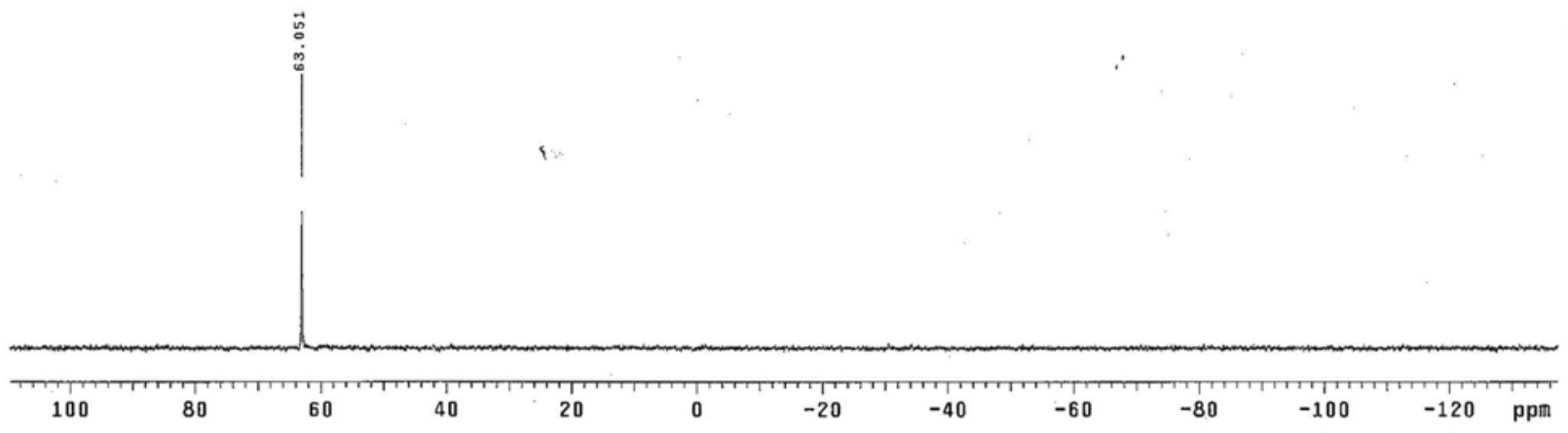

Figure S3. ${ }^{31} \mathrm{P}$ NMR spectrum of $\left[\mathrm{cHex}_{2} \mathrm{P}(=\mathrm{O}) \mathrm{NC}_{5} \mathrm{H}_{4}-4-\mathrm{OCH}_{3}\right]^{+} \mathrm{Cl}^{-}$. 
Print Date: 15 Apr 2011 16:46:30

\section{MS Data Review All Plots - 4/15/2011 4:46 PM}

File: ...anwsldataltest_scanlchemistrylprof_leehaehwangl20110415lwoolhuk.xms

Sample: woolhuk
Scan Range: 1 - 2955 Time Range: 0.15 - $32.58 \mathrm{~min}$. GCounts

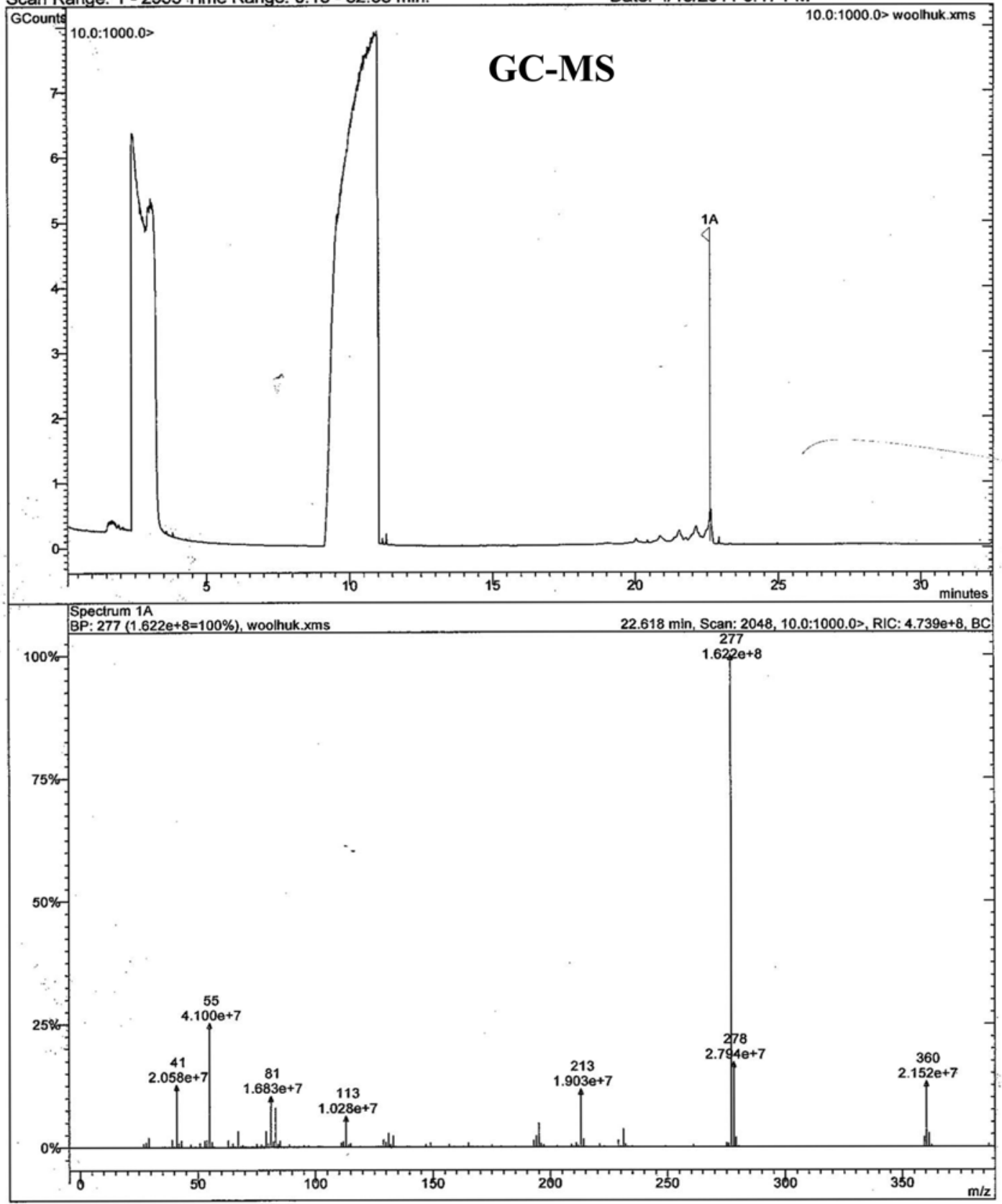

Figure S4. GC-MS spectrum of $\left[\mathrm{cHex}_{2} \mathrm{P}(=\mathrm{O}) \mathrm{NC}_{5} \mathrm{H}_{4}-4-\mathrm{OCH}_{3}\right]^{+} \mathrm{Cl}^{-}$. 